\title{
Music Acculturation in Rhythm of kapang-kapang Bedhaya and Srimpi Dance in the Keraton of Yogyakarta \\ (A Case Study)
}

\section{R.M. Surtihadi}

Indonesia Institute of the Arts, Yogyakarta email: surtihadihadi@gmail.com

\begin{abstract}
The research's aim is to notice the music acculturation in the rhythm of female dance of Bedhaya and Srimpi dances in the Kingdom of Yogyakarta on the line-movement on-to the stage or leaving it (kapang-kapang). Besides, the research is going to discuss a West music instrument acculturation phenomenon with Javanese Traditional Gamelan Orchestra on the rhythm of female dance of Bedhaya and Srimpi dances that are still exist nowadays. The case study is focus on the usage of some West music instrument such as drum (percussion section), woodwind (woodwind section), brass-wind (brass-wind section), and stringed (stringed section) in the rhythm of the dances which are being mentioned above. The method which is being used first is by doing the quality data analysis. The result of the research are two mainly findings; those are 1) the inclusion of various elements of the palace ceremonial ritual by The Netherlands Indies government which were the impact of the European Colonization in the island of Java, especially in Yogyakarta; it has made a mentally structure of the people of Yogyakarta that would have created culture capitalized and which are being used in the context of Yogyakarta as the city of culture. 2) European military music for marching is being the inspiration of the palace to create Gendhing Mars which is being used as the rhythm in the marching movements of female dancers (kapang-kapang) together along with the ensemble of Javanese Traditional Gamelan Orchestra and the European music instruments which are being played in one sound (unisono).
\end{abstract}

Keywords: acculturation, music, and dancing rhythm. bottom of form

\section{INTRODUCTION}

The encounter between Javanese Traditional Gamelan Orchestra and the music in The Kingdoms in the island of Java have been happening centuries ago. Especially, in The Kingdom of Yogyakarta as the centre of Javanese culture has the important historical fact as the centre of exellence, it has a palace characteristic. Various cultural activities have been developing ever since. However, the developments that have been happening were mostly because of the interaction between local and foreign culture. In the scope of art especially in music, it has started from military music. Military music in Yogyakarta Palace has been emerged since the government of Sultan Hamengku Buwana I (1756-1792). As being said by Ricklefs (1974: 87), The Netherlands Indies government has given some palace protocol ceremonial complements such as horse carriage, elephants, Persian horses and some trumpet players to give honor ala European to The Kingdom of Yogyakarta. 
In the scope of art in The Kingdom of Yogyakarta, West music instruments are being used as the rhythm in the dances, which are being combined with the Javanese Traditional Gamelan Orchestra. In some female dances such as Bedhaya and Srimpi, on the marching movements when the dancers are come-out and come-in on the stage (kapang-kapang) the rhythm is a mix between two instruments, those are Javanese Traditional Gamelan Orchestra and West music instruments such as trumpets and drum. Besides, muscular dances Lawung Ageng of Yogyakarta Palace is having a rhythm from Javanese Traditional Gamelan Orchestra and West music instruments, but now we are focus on the female dances only.

Babad Ngayugyakarta volume III gives important information toward the historical review on this particular writing. Babad Ngayugyakarta the as a journal of the sultan who was rulled, contains the sultan's activities and his works on the time he was rulled. The information gathered from the source is about the occasions of culture relations which was being begun by protocol ceremony up to the activities of art and culture.

A writing source intitled Keraton nDalem Ngayugyakarta Pagelaran (Kartahasmara, 1990), gives informations about the data of Yogyakarta Sultan works when he was rulled (Yasan Dalem) from Sultan Hamengku Buwana (HB) I up to Sultan HB VIII. In this kind of source has been found informations about the activities of art and culture which were related to the usage of the West music instruments and Javanese Traditional Gamelan Orchestra as the rhythm of the dances in the Yogyakarta Palace. From the document mentioned, which is containing about the form of music acculturation culture in the music of Javanese Traditional Gamelan Orchestra and West music instruments, the information is written in the data of Yasan Dalem Sultan HB V (19231955) and Sultan HB VIII (1921-1939).

The Periode of The Rulled of Sultan Hamengku Buwana V (1823-1855)

As already being explained in the Introduction, the period of the rulled of Sultan Hamengku Buwana V (1923-1955) has happened a contact with the foreign culture that it settled into Javanese culture (palace) by the acculturation of West music instruments either in the music rhythm of Javanese dances and protocol ceremony. If the statements were an indication of historical period, then the sources that can be used as an occasion of the cultural contact was more as a character of limited relation in the protocol ceremony and in the scope of art. It is because of one reason that the statement has already being explained in Babad Ngayugyakarta about the occasions of culrural contacts which was being begun by the protocol ceremony by which it effected on the scope of art.

It is a quotation of Ngayogyakarta Pegelaran which explains a process of music acculturation in the era Sultan HB V:

\section{Murjani Yasa Gendhing-gendhing sabrangan kanthi}

Kairing ungeling musik trumpet, tambur, bedhug lan sasaminipun. Kagem Nggangsani Kapang-kapang Majenging/munduripun Lelangen Dalem Bedhaya, 
Sarta Beksan Trunajaya. Ingkang nindakaken nggarap

Jumbuhing gangsa lawan musik tiyang Walandi

Inggih Van Gough sarta Smith. (Kartahasmara, 1989: 191).

Translated into:

9. Start to make gendhing-gendhing sabrangan

by the rhythm of the sounds of trumpet, drum, bedhug, and so on. As a rhythm os

Kapang-kapang forward/backward of Lelangen Dalem

Bedhaya, also Beksan Trunajaya. The persons who

do the work of the harmony of javanese Gamelan orchetra with

the music of The Dutch were Van Gought and Smith.

In the source text above, it can be related to the state of a Sultan as an autority holder; the assumption as that the concept of the power of autority holder influenced the other concepts of lives including the work of art (Soedarsono, 1989:1-5). Then, it could be stated that some thermonology languages such as Karsa Dalem, Dhawuh Dalem, Yasan Dalem, Lelangen Dalem, and so on, could be valid if it is related to the concept of the rulled of Sultan and the relation with the concept of art (Soedarsono, 1989 : 1-5).

The Periode of The Rulled of Sultan Hamengku Buwana VIII (1921-1939)

The examination of the art historical periode in the Yogyakarta Palace is more interesting in the rulled of Sultan Hamengku Buwana VIII (1921-1939); it is because of West culture is more real in entering the art concept in Yogyakarta Palace. Ngayugyakarta Pagelaran explains more about the state of the influence in the data of Yasan Dalem in the period of Sultan Hamengku Buwana VIII (1921-1939) as:

Karsa Dalem njangkepi iringaning Kapang-kapang Bedhaya/Srimpi, Beksan Trunajaya, Srimpi Pandelori miwah Srimpi Muncar, kanthi tambahan musik gesek/biola (Kartahasmara, 1989 : 193).

Translated into:

Karsa Dalem completed the rhythm Kapang-kapang Bedhaya/Srimpi, beksan Trunajaya, also Srimpi Pandelori and Srimpi Muncar, by the addition of stringed music instrument/violin.

In the quotation taken from Ngayugyakarta Pagelaran above, is so much clear that the addition of stringed instruments/violin in the rhythm music of the dances, was as a willing of Sultan Hamengku Buwana VIII. It is known that in the period of the rulled of Sultan Hamengku Buwana VIII (1921-1939), Yogyakarta Palace had a Orchestra Music Corps by the musical conductor of Walter Spies (Rhodius, Darling, 1980 : 21-27).

The developments of palace art exibition was conspicuous in the period of Sultan HB VIII (1921-1939). Especially in the rhythm music of the dances, The Javanese Tradional Gamelan Orchestra has being improoved, and various gendhing-gendhing has created to be the music rhythm of samoe dances and wayang wong (people as puppet characters). 
Sultan Hamengku Buwana VIII has fully motivated the art experts to create as so many creations emerged to be richer and more alive music rhythm; even more because Sultan had some art experts such as K.R.T. Wiroguno, K.R.T. Purbaningrat, K.R.T. Madukusumo, R.W. Larassumbogo and many others; even the West music instruments has being developed to be a music rhythm for beksan. Two western music experts, Spies and Gotsch were asked to train the exist musicians (Suharto, 1981 : pp.119-121).

The name and the type of gendhing Gati (Gendhing gati is a title of a song as arhythm music of dances with marching, so it is called gendhing mares), which is being used as the music rhythm for Kapang-kapang Bedhaya and Srimpi:

Gendhing Gati Brongto

Gendhing Gati Raja

Gendhing Gati Mardawa

Gendhing Gati Padasib

Gendhing Gati Wiwaha

Gendhing Gati Sangaskara (Soerjadiningrat, 1980 : pp. 35-39)

\section{DISCUSSION}

Culture acculturation is one of the culture changing phenomenons which were a caused of the engagement of two different cultures or more. In the process of the acculturation, there are some matters that influenced the engagement or the culture contact itself. According to Lauer (2003), the matters that influenced the culture acculturation were the war, the colonization, conqueror, and military expansion, migration, trading, tourism and mass media.

According to the study above, which is about a process of social changes, the position of the mix of two kinds of instruments, those are (Gamelan) Traditional Javanese Orchestra and West music instruments, the trumpet; and the drum of Yogyakarta Palace is one of the culture acculturation phenomenon. If we examined from the process of the existence, this kind of music has made from two cultures, Javanese and European. Both could be observes from the use of music instruments. The European music instruments included the trumpet, and the drum while the Javanese music instruments are a set of Traditional Javanese Orchestra Javanese Gamelan) with laraspélog (Laraspélog is one of the Javanese tune that are being used in gamelan Jawa).

The process of the engagement between Javanese and European culture was becoming the background of the music type of the music rhythm of Yogyakarta Palace dances; it inspired of European military music, by then after the accultarion it is being called gendhing mares as the music rhythm of female dances Bedhaya and Srimpi. The important events that influenced it were the trading and military conqueror, which both could not be separated from European colonization toward the island of Java. It is appropriate to the concepts of Lauer about the process of culture acculturation. Up to these days the music rhythm of kapang-kapang Bedhaya and Srimpi dances of Yogyakarta Palace has been exist. It is more now becoming the main capital that supported the position of Yogyakarta as the City of Culture. 
The question that is appearing now, why does the particular music has been survived up to these days? This is analyzed by the concepts of habitués and culture capital by Pierre Bourdieu. There are some characteristics of main habitués. Those are longlasting, could be transfered, structures that are structurelised, and structures that are being structured (Bourdieu 1993: 162). The Bourdieu Concept could help to know the factors that caused the agents to fulfilled the certain positions in the arena of the battle. The arena which was being mentioned in the writing is the position of Yogyakarta as The City of Culture.

Based on the matter, it could be seen that the process of European colonization, which was at the same time with the trading and also the military conqueror in the island of Java, which has been taking in a long time, un-automatically shaped the mentally structure of the people of Java, especially the people in the Kingdom of Yogyakarta. This is the habitués of Yogyakarta Palace and it converses into culture capital. As the other Bourdieu's point of view, Capital is being used to describe gambling in social arena (Jenkins: 128). This is becoming the main reason by Yogyakarta Palace as gambling in the context of the culture city.

\section{CONCLUSION}

The existence of West music instruments in Yogyakarta in the period of the rulled of Sultan Hamengku Buwana I (1755-1792) has started by the donation of trumpet from the Dutch to complete the need of palace. The existence of the West music instrument has been continued in the period of the rulled of Sultan Hamengku Buwana II (1792-1810) by the appearance of the positions of abdi Dalem tambur suling salompret, the therminology is based on the trumpet players. The harmony of the West music instrument (trumpet and drum) with the Traditional Javanese Orchestra (gamelan) Jawa has been made in the period of the rulled of Sultan Hamengku Buwana V (18231855) as the rhythm music for beksan Kapang-kapang Srimpi andn Bedhaya, and also as the music rhythm for beksan Lawung Ageng by the two Dutch people Van Gought and Smith as the command of Sultan. The harmony of West music instruments and (gamelan) Javanese Traditional Orchestra has made its peak in the period of the rulled of Sultan Hamengku Buwana VIII (1921-1939); it was when Sultan had a complete West diactonic Music Corps with Walter Spies as the musc director. The music rhythm for kapang-kapang Bedhaya and Srimpi or beksan Lawung Ageng accompanied by the complete orchestra which included stringed instruments, woodwind instruments, brass-wind instruments and percussions.

The process of colonization which accompanied along the military conqueror and trading has become the main factor of the emerged of culture acculturation of music on the music rhythm for the dances of kapang-kapang bedhaya and srimpi of Yogyakarta Palace. Then, European colonization I the island of Java especially in Yogyakarta has made a mental structure of the people of Yogyakarta that has shaped the culture capital and it is being used in the context of Yogyakarta as the city of culture. 


\section{REFERENCES}

Babad Ngayogyakarta, Vol. III, Yogyakarta: Perpustakaan Museum Sana Budaya Yogyakarta.

Bourdieu, Pierre.1993. The Field of Cultural Production, Essayis on Art and Literature. US: Colombia University Press.

H. Lauer, Robert. 2003. Perspektif Tentang Perubahan Sosial. Bandung: Rineka Cipta.

Kartahasmara, R.Ng. 1990. Ngayugyakarta Pagelaran. Transliterasi Wibatsu Harianto Soembogo. Yogyakarta: Mahadewa.

Rhodius, Hans. Darling, John, 1980, Walter Spies and Balinese Art, Amsterdam: Terra, Zutphen.

Ricklefs, M.C., 1974. Jogjakarta Under Sultan Mangkubumi (1749-1792), A History of The Division of Java, London: Oxford University Press.

R.M. Soedarsono, 1989. "Raja Jawa dan Seni: Sebuah Contoh Pengaruh Konsepsi Seni Pertunjukan". Makalah Ceramah pada Proyek Penelitian dan Pengkajian Kebudayaan Nusantara, Bagian Jawa, 25 September 1989.

2010. Seni Pertunjukan Indonesia di Era Globalisasi, Yogyakarta: Gadjah Mada University Press.

R.M. Surtihadi. 1995. "Instrumen Musik Tradisi Barat Dalam Iringan Tari dan

Upacara Protokoler Kraton Yogyakarta (Sebuah Tinjauan Historis)". (Thesis). Yogyakarta: Fakultas Seni Pertunjukan, ISI Yogyakarta.

Soerjodiningrat, Wasisto. 1980. Gendhing Beksan Mataraman, Yogyakarta: Proyek Peningkatan Pengembangan Perguruan Tinggi, Sub Proyek Festival Seni Budaya.

Suharto, Ben. 1981. "Perkembangan Tari Klasik Gaya Yogyakarta" dalam Fred Wibowo (ed.). Mengenal Tari Klasik Gaya Yogyakarta. Yogyakarta: Dewan Kesenian Prop. DIY.

Sumarsam, 2003. Gamelan, Interaksi Budaya dan Perkembangan Musikal di Jawa, Yogyakarta: Pustaka Pelajar.

Base line data to read notation which has been transcript from the music of the Traditional Javanese Orchestra (gamelan) into notation of the music of the West is as:

To read the notation of gendhing which has already trsncript into cross-bar (especially in the music rhythm for kapang-kapang), the musicians have to be able to understand the phrases in the sentences in gendhing which is ended by the sound of big instrument of gong. It caused the ending of the music is never on the end of its sentences of the music. The music can be stopped in the middle or at the front part of the sentences of its music, which is always end up by the sound of a big instrument called big gong. As the music thythm for the dances of bedhaya or srimpi, it has to synchronize with the duration of the section of kapang-kapang, which are always different. The size (big or small) of the stage or pendapa (the front part of the Javanese Traditional House) as the place to dance is really influence on the duration of the music rhythm. 
R. M. Surtihadi, Music Acculturation in Rhythm of ...

\section{GATI WIWAHA}

BUKA BONANG

ORKES MASUK

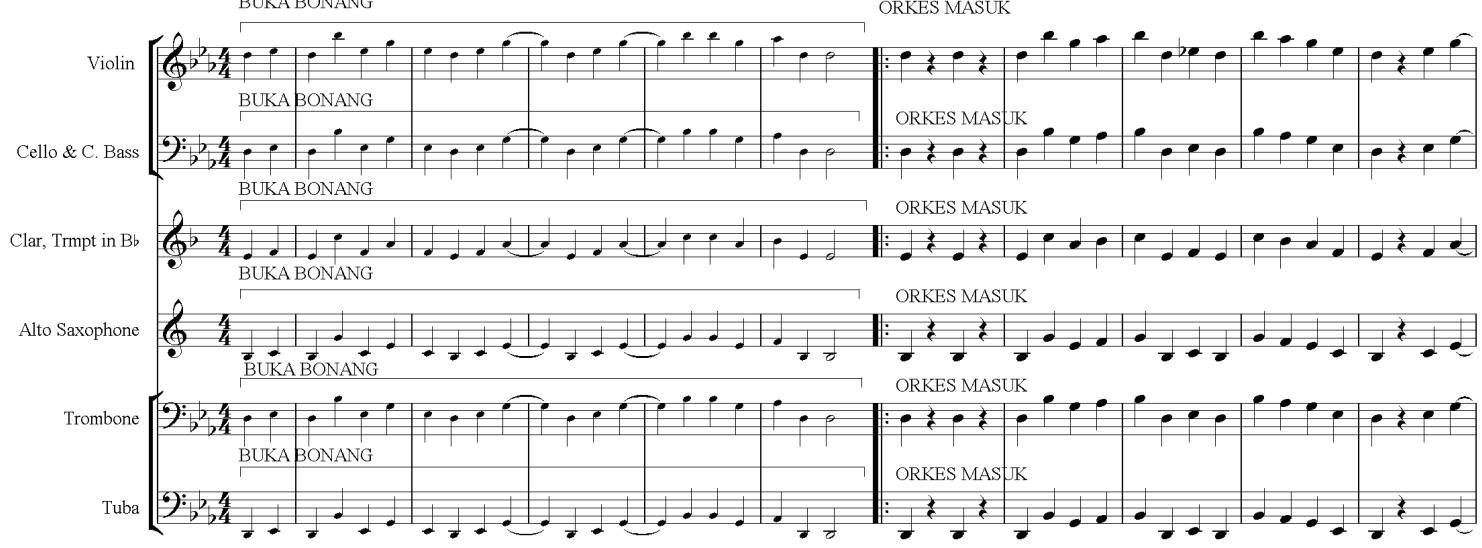

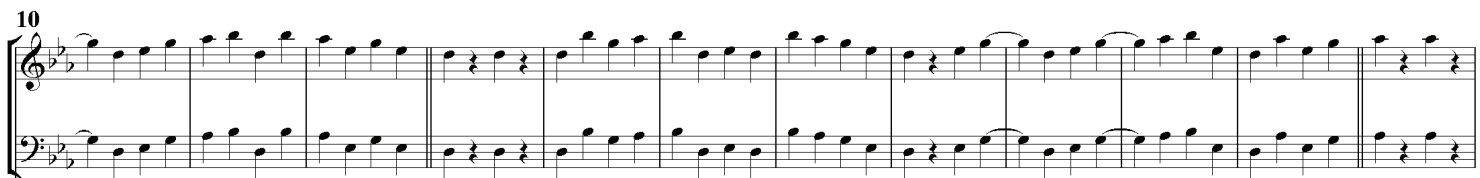

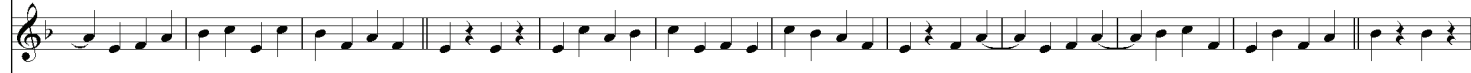

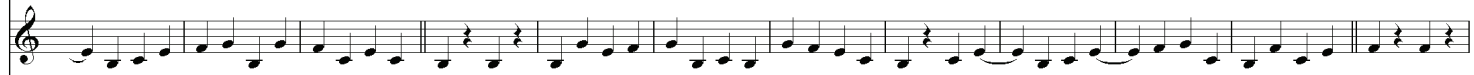

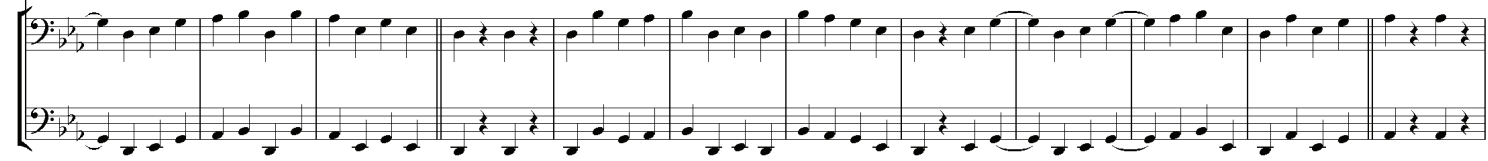

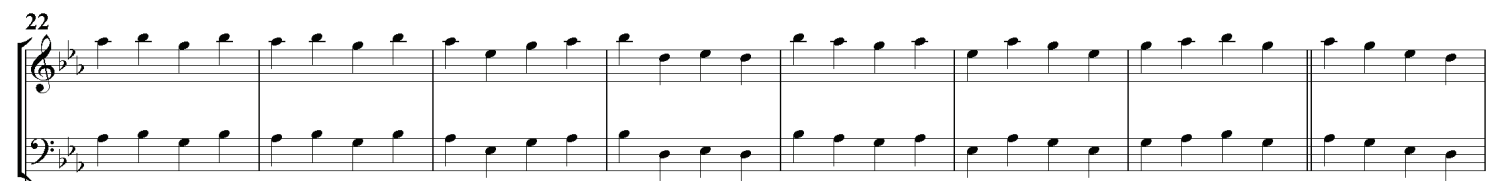

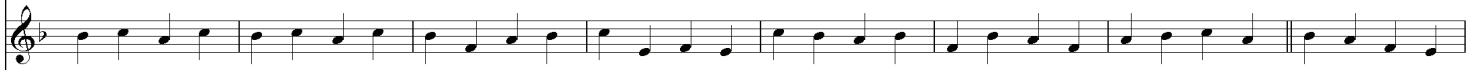

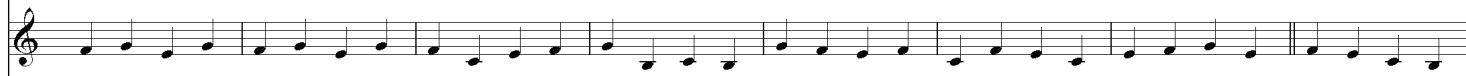

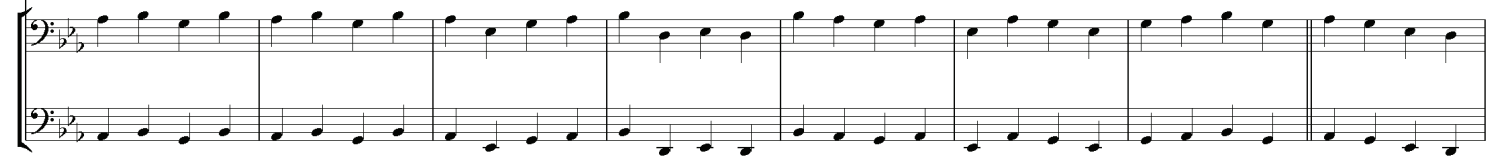

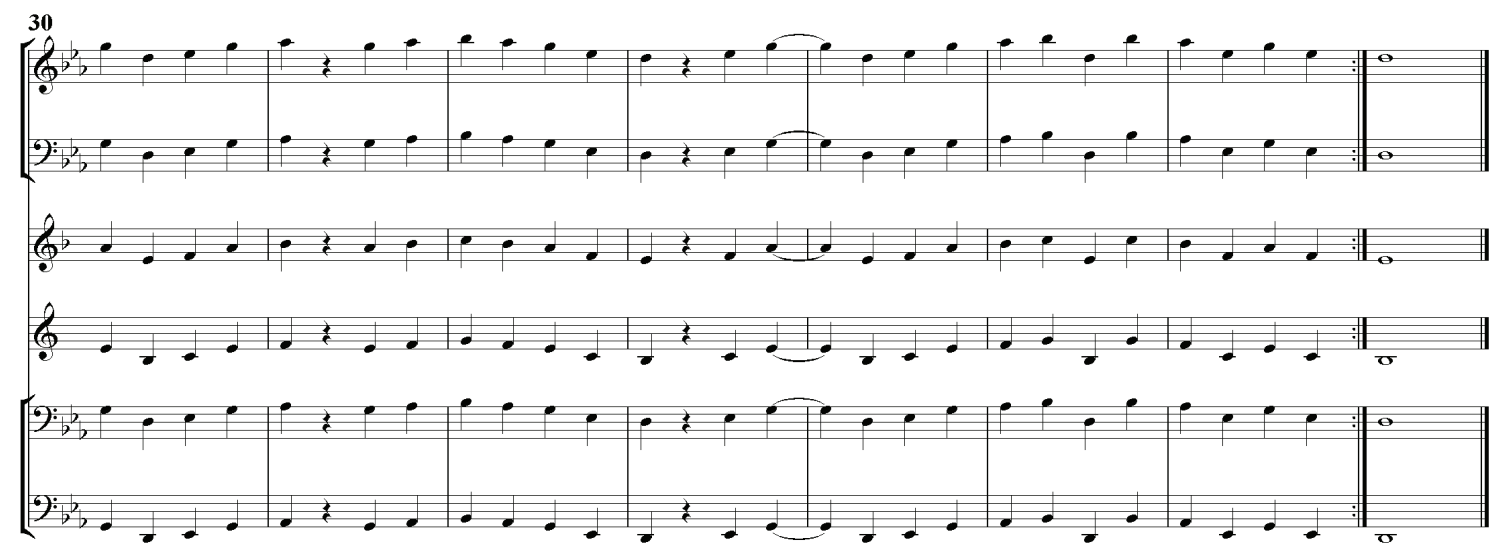




\section{GATI SANGASKARA}

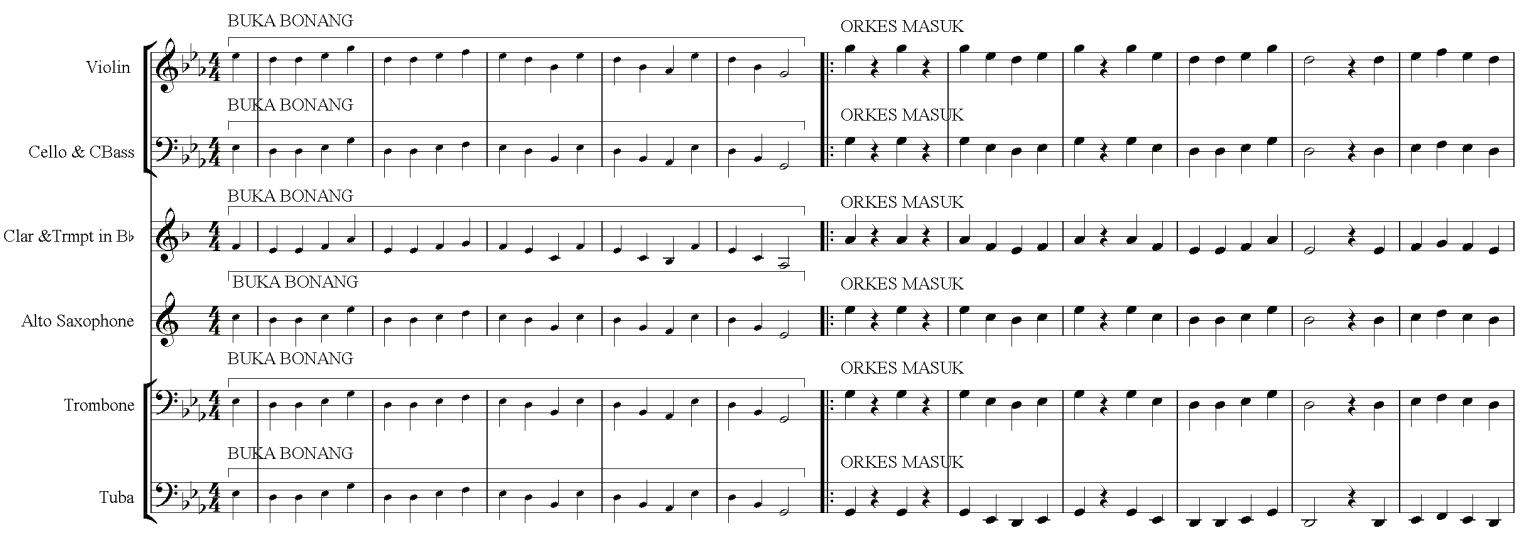

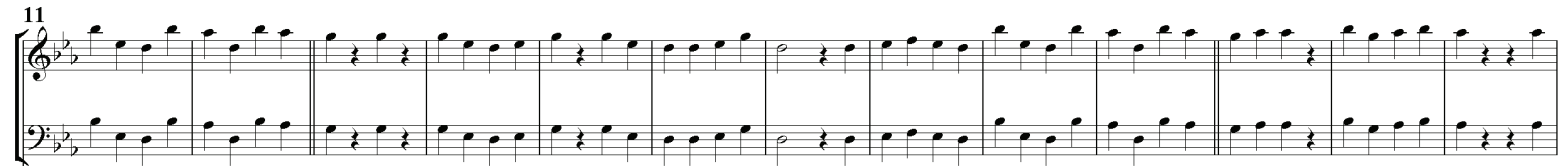

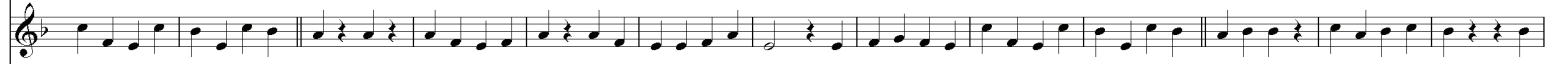
$\ell_{6} \cdots \cdots \cdots$

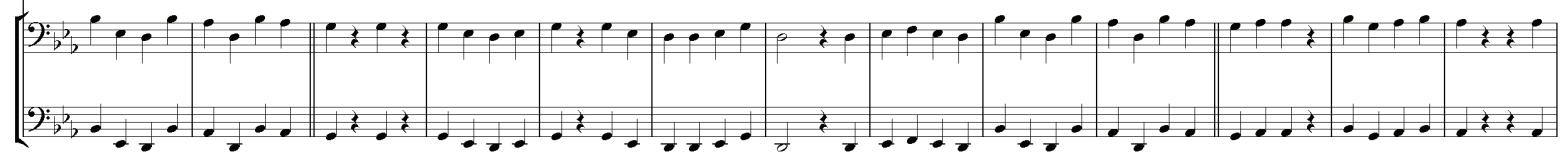

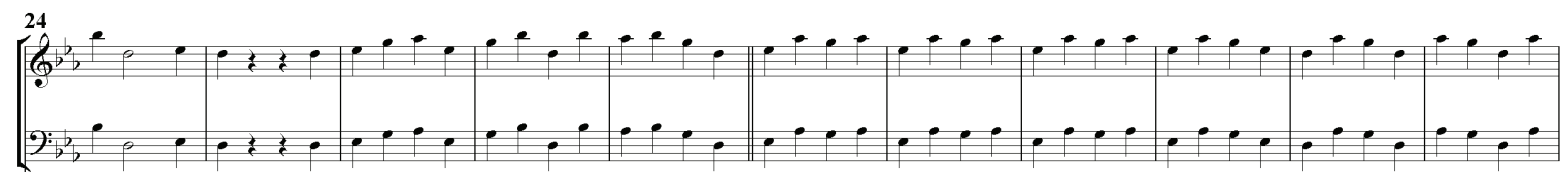

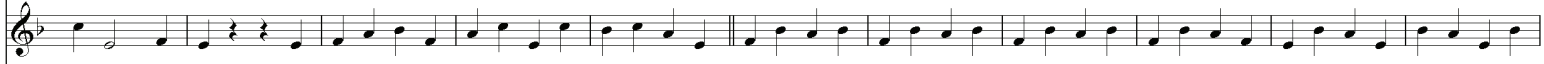

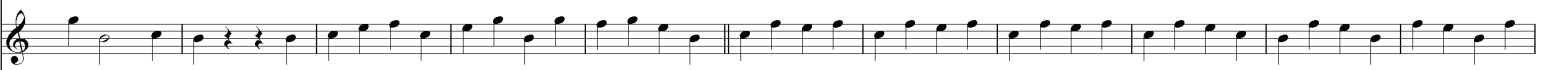

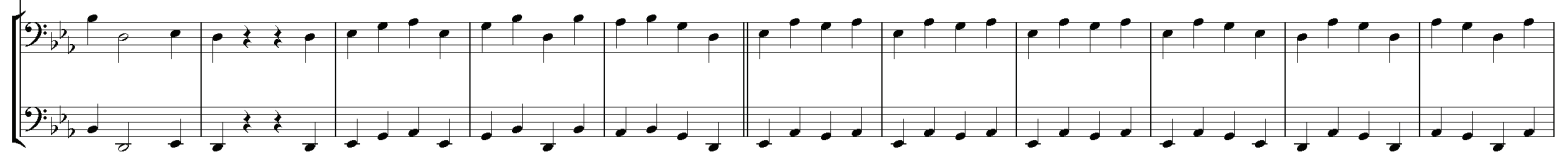

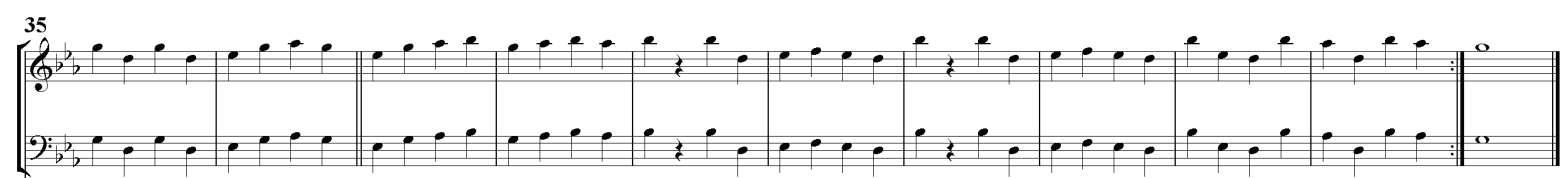

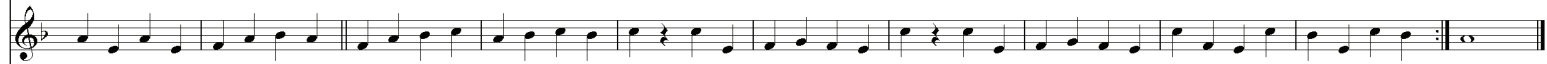

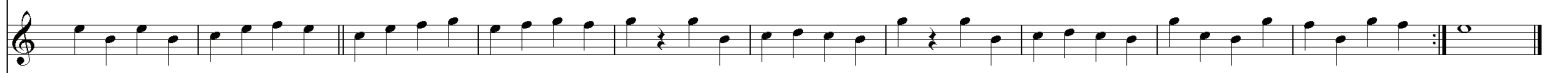

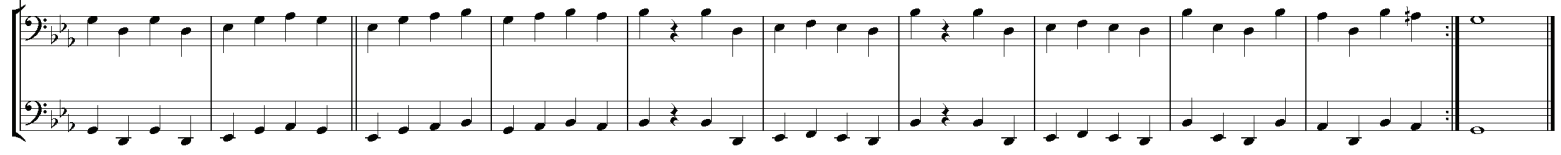

